\title{
HUBUNGAN KONSEP DIRI DAN DUKUNGAN SOSIAL DENGAN PENYESUAIAN DIRI PADA REMAJA DI PANTI SOSIAL BINA REMAJA TARUNA JAYA TEBET JAKARTA
}

\author{
Indri Arsita, Rilla Sovitriana
}

\author{
Universitas Persada Indonesia YAI
}

\begin{abstract}
ABSTRAK
Penyesuaian diri remaja di panti merupakan suatu usaha yang dilakukan oleh remaja untuk mempertemukan tuntutan diri sendiri dengan lingkungan, baik secara aktif maupun pasif yang melibatkan respon mental dan tingkah laku. Faktor yang mempengaruhi penyesuaian diri diantaranya ada konsep diri dan dukungan sosial. Tujuan penelitian ini untuk mengetahui apakah ada hubungan konsep diri dan dukungan sosial dengan penyesuaian diri pada remaja di panti sosial bina remaja taruna jaya Tebet Jakarta. Jenis penelitian ini adalah penelitian kuantitatif . Yang menjadi populasi dalam penelitian ini adalah remaja binaan sosial taruna jaya yang berjumlah 42 subjek. Metode pengambilan data menggunakan teknik sampling jenuh. Hasil analisis data dengan menggunakan regresi multivariate diperoleh nilai $\mathrm{R}$ sebesar 0,544 yang berarti ada hubungan positif antara konsep diri dan dukungan sosial dengan penyesuaian diri, analisis data variabel konsep diri dengan penyesuaian diri diperoleh nilai koefisien korelasi ( $r x y 1)=0,448$ yang berarti ada hubungan positif antara konsep diri dengan penyesuain diri, analisis data veriabel dukungan sosial dengan penyesuain diri diperoleh nilai koefisien korelasi (rxy2) $=0,432$ yang berarti ada hubungan positif antara dukungan sosial dengan penyesuain diri.
\end{abstract}

Kata kunci : Konsep Diri, Dukungan Sosial, Penyesuaian Diri 


\section{PENDAHULUAN}

Masalah sosial sekarang ini terus berkembang seiring berjalannya waktu, terlebih di Ibukota Jakarta, banyak masalah sosial yang setiap tahunnya bermunculan. Jakarta menjadi pilihan warga urban karena merupakan pusat kota yang banyak orang berkeinginan untuk kehidupan yang lebih baik, namun kenyataannya banyak masalah sosial bermunculan di Jakarta. Salah satunya adalah anak jalanan,anak terlantar dan remaja bermasalah. Dari pusat kota hingga sudut kota sudah menjadi pemandangan biasa anak - anak dan remaja beradu nasib dijalanan sebagai pengamen, pengemis ataupun remaja"punk".

Menurut Khofifah selaku Menteri Sosial, Dani Prabowo (2016, para 5), tercatat hingga saat ini jumlah anak jalanan di Indonesia pada tahun 2015 yaitu 33.400, dan data terbanyak berada di Provinsi DKI Jakarta yaitu 7600 anak jalanan. Jumlah anak jalanan di Jakarta tidak semuanya berasal dari Jakarta saja, sebagian besar justru berasal dari luar Jakarta.Latar belakang keluarga menjadi salah satu alasan adanya anak jalanan dan remaja bermasalah. Kesulitan ekonomi menjadi salah satu faktornya, banyak orang tua yang tidak mampu memenuhi kebutuhan anak secara materi sehingga banyak anak yang turut ikut mencari nafkah dijalan. Sebagian besar anak jalanan dan remaja bermasalah tidak melanjutkan sekolah atau putus sekolah. Hal ini membuat remaja menjadi tidak memiliki masa depan yang baik.

Hurlock ( dalam Fani,Latifah 2012 : 21 )Masa remaja dianggap sebagai masa labil yaitu remaja berusaha mencari jati dirinya dan mudah sekali menerima informasi dari luar dirinya tanpa ada pemikiran lebih lanjut. Remaja yang seharusnya masih butuh pengarahan dari orang tua untuk mencari jati dirinya, namun dengan adanya masalah sosial yang menjadikan remaja sebagai anak jalanan dan harus mencari nafkah membuat remaja menjadi sulit menemukan jati dirinya. Tidak sedikit remaja yang menghabiskan waktu dijalanan terjerumus pada hal - hal yang negatif. Remaja jalanan yang seharusnya masih mengenyam pendidikan terpaksa harus meninggalkan pendidikannya karena faktor biaya.

Khusus untuk remaja bermasalah sosial, seperti remaja putus sekolah dan anak jalanan, pemerintah daerah Jakarta memiliki Panti Sosial Bina Remaja ( PSBR ). PSBR merupakan wadah arau tempat membina remaja bermasalah sosial agar memilkiketerampilan, seperti ketermapilan dalam bidang tata busana, tata boga dan lainsebagainya.Adanya PSBR memberikan harapan kepada remaja untuk memiliki masa depan yang baik.Hasil wawancara peneliti dengan pengurus PSBR Taruna Jaya Tebet, saat awal masuk panti, remaja ada yang diantar oleh orang tua yang mengaku kurang mampu membiayai anaknya dan ada pula yang berasal dari panti sosial asuhan anak . Remaja yang diantar oleh orang tuanya untuk di bina di PSBR harus mengikuti syarat dan prosedur yang sudah ditentukan. Bagi remaja yang berasal dari panti sosial asuhan anak, remaja tersebut dirujuk untuk dibina di PSBR. Pengurus panti mengaku pada saat awal masuk ada beberapa kasus remaja yang kabur dengan masalah sulit menyesuaikan diri dengan lingkungan di panti.

Remaja yang kabur merasa tidak nyaman dengan lingkungan panti yang penuh peraturan yang harus ditaati, namun tidak jarang juga setelah kabur ada yang kembali lagi.

Ada beberapa masalah penyesuaian diri yang dialami remaja dipanti, selain harus menaati peraturan panti, remaja juga memiliki kesulitan menyesuaikan diri dengan penghuni panti lainnya, yaitu dengan pengasuh dan teman sebaya.

Selama tinggal di panti remaja membutuhkan penyesuaian diri dengan lingkungan di panti. Atwater ( dalam 
Ida,Putu 2016:554 ) penyesuian diri merupakan perubahan yang terjadi dalam diri individu dan lingkungan sekitar untuk mencapai suatu hubungan yang memuaskan dengan orang lain dan lingkungan. Dijelaskan juga oleh Willis ( dalam Fani,Latifah 2012:21 ) penyesuaian diri menuntut kemampuan remaja untuk hidup dan bergaul secara wajar terhadap lingkungannya, sehingga remaja merasa puas terhadap diri sendiri dan lingkungannya. Remaja yang tinggal di panti dapat menyesuaikan diri dengan membaur dan sering berinteraksi dengan teman sebaya maupun pengasuh di panti.

Penelitian Ida dan Putu ( 2016 : 542) ,menunjukkan proses penyesuaian diri pada remaja di panti asuhan dapat diatasi dengan pemberian beberapa aktivitas yang memungkinkan remaja di panti asuhan yang apabila memiliki penyesuaian diri rendah dapat berbaur dengan penghuni panti asuhan yang lainnya yang memiliki kemampuan penyesuaian diri yang baik. PSBR pun mempunyai beberapa kegiatan selain keterampilan, seperti kegiatan olahraga, kesenian hingga kegiatan kewarganegaraan seperti upacara atau apel Setiap hari senin. Kegiatan yang dilakukan menghasilkan remaja di panti membaur dan mudah menyesuaikan diri.

Penelitian Ida dan Putu (2016 : 542) menunjukkan remaja di panti dengan penyesuaian diridianalisis melalui kemampuan remaja di panti dalam mengatasi masalah yang terjadi dengan mengontrol emosi yang baik, serta memiliki gambaran diri positif juga mampu menjalin hubungan interpersonal yang baik dengan orang lain. Salah satu kemampuan untuk mengatasi penyesuaian diri remaja di panti adalah konsep diri. Chaplin ( dalam Yudit, 2008:147) mengemukakan bahwa konsep diri adalah evaluasi individu mengenai diri sendiri, penilaian atau penaksiran mengenai diri sendiri oleh individu yang bersangkutan. Sedangkan menurut Hurlock ( dalam
Gufron dan Rini, 2014:13) mengatakan bahwa konsep diri merupakan gambaran seseoang mengenai diri sendiri yang merupakan gabungan dari keyakinan fisik, psikologis, sosial, emosional aspiratif, dan prestasi yang mereka capai. Konsep diri juga merupakan gambaran seseorang tentang dirinya, yang dibentuk melalui pengalaman-pengalaman yang di peroleh dari interaksi dengan lingkungan.Remaja di panti yang memiliki konsep diri yang positif akan lebih mudah menyesuaikan diri di lingkungan panti, baik dengan teman sebaya ataupun dengan pengasuh.

Bagi remaja yang tinggal di panti, lingkungan panti merupakan lingkungan sosial utama yang dikenal, sehingga remaja perlu melakukan penyesuaian diri sesuai dengan lingkungan di panti, dan kebutuhan yang dituntut dari lingkungan tersebut agar proses pencapaian keharmonisan dalam mengadakan hubungan yang memuaskan bersama teman sebaya dan pengasuh. Rook (dalam Fani,Latifah 2012:25 ) mengatakan bahwa dukungan sosial merupakan salah satu fungsi dari ikatan sosial, dan menggambarkan tingkat kualitas umum dari hubungan interpersonal. Remaja dalam mencapai penyesuaian diri yang maksimal memerlukan dukungan sosial dari orang terdekat dilingkungannya yaitu dengan pengasuh dan teman -teman sesama penghuni pantiDalam penelitian Fani dan Latifah (2012:21) menyatakan hasil penelitian analisis data menunjukkan bahwa ada hubungan antara dukungan sosial dengan penyesuaian diri remaja di panti asuhan.

Penyesuaian diri remaja di panti merupakan suatu usaha yang dilakukan oleh remaja untuk mempertemukan tuntutan diri sendiri dengan lingkungan, baik secara aktif maupun pasif yang melibatkan respon mental dan tingkah laku. Sehingga tercapai hubungan yang harmonis antara diri remaja dengan lingkungan panti.Adannya konsep diri yang dimiliki remaja, dengan mudah remaja dapat menyesuaikan diri dengan 
lingkungan panti baik dengan pengasuh maupun dengan teman sebaya.Remaja di panti juga membutuhkan dukungan sosial untuk menyesuaikan diri di lingkungan panti. Dukungan sosial menunjukkan pada hubungan interpersonal yang melindungi individu terhadap konsekuensi negatif dari stress. Dukungan sosial yang diterima dapat membuat individu merasa tenang, diperhatikan, dicintai, timbul rasa percaya diri dan kompeten.

\section{TUJUAN PENELITIAN}

Tujuan penelitian ini adalah untuk mengatahui:

1.Untuk mengetahui hubungan konsep diri dengan penyesuaian diri pada Remaja di PSBR Taruna Jaya Tebet Jakarta.

2. Untuk mengetahui hubungan dukungan sosial dengan penyesuaian diri pada remaja di PSBR Taruna Jaya Tebet Jakarta.

3. Untuk mengetahui hubungan konsep diri dan dukungan sosial dengan penyesuaian diri pada remaja di PSBR Taruna Jaya Tebet Jakarta.

\section{TINJAUAN PUSTAKA}

\section{Penyesuaian Diri}

Menurut

Schneider

(Hendriati,2009:146 ) bahwa penyesuaian diri merupakan satu proses yang mencakup respon - respon mental dan tingkah laku, yang merupakan usaha individu agar berhasil mengatasi kebutuhan, ketegangan, konflik dan frustrasi yang dialami dalam dirinya. Usaha tersebut bertujuan untuk memperolehkeselarasan dan keharmonisan antar tuntutan dalam diri dengan apa yang diharapkan oleh lingkungan.

Faktor- faktor yang mempengaruhi penyesuaian diri Scheneider ( dalam Sunarto, 2002:229) yaitu, kondisi jamaniah, perkembangan, pematangan dan penyesuaian diri, penentu psikologis terhadap penyesuaian diri, lingkungan,
Menurut Runyon dan Haber ( dalam Putri Rosalia, 2013: 73) ada lima aspek dalam penyesuaian diri, yaitu :

a. Persepsi terhadap realitas, Individu mengubah persepsinya tentang kenyataan hidup dan menginterpretasikannya, sehingga mampu menentukan tujuanrealistis sesuai dengan kemampuannya serta mampu mengenali konsekuensi dan tindakannya agar dapat menuntun pada perilaku yang sesuai.

b.Kemampuan menghadapi stress dan kecemasan berarti individu mampu mengatasi masalah-masalah yang timbul dalam hidup dan mampu menerima kegagalan yang dialami.

c.Gambaran diri yang positif, yaitu berkaitan dengan penilaian individu tentang dirinya sendiri.

d. Kemampuan mengekspresikan emosi dengan baik berarti individu memiliki ekspresi emosi dan kontrol emosi yang baik dan tidak berlebihan.

e. Hubungan interpersonal yang baik berkaiatan dengan hakekat individu sebagai makhluk sosial, yang sejak lahir tergantung pada orang lain. Individu yang mempunyai penyesuiaan diri yang baik mampu membentuk hubungan dnegan cara yang berkualitas dan bermanfaat.

\section{Konsep Diri}

Menurut William H. Fitts (Hendriarti, 2009:139) mengemukakan bahwa konsep diri merupakan aspek penting dalam diri seseorang, karean konsep diri seseorang merupakan kerangka acuan ( Frame of reference) dalam berinteraksi dengan lingkungan.

Menurut Fitts (Hendriarti, 2009:139) membagi konsep diri dalam dua dimensi pokok, yaitu,

\section{a. Dimensi Internal}

Dimensi internal atau yang disebut juga kerangkan acuan internal adalah penilaian 
yang dilakukan individu yakni penilaian yang dilakukan individu terhadap dirinya sendiri berdasarkan dunia didalam dirinya. Dimensi ini terdiri dari tiga bentuk :

1) Diri Identitas ( identity self)

2) Diri Pelaku ( behavioral self)

3) Diri Penerimaan / Penilai ( Judging self )

b. Dimensi Eksternal

1) Diri fisik ( physical self)

2) Diri etik/moral (moral/ethical self)

3) Diri pribadi (personal self)

4) Diri keluarga ( family self)

5) Diri sosial ( social self)

\section{Dukungan Sosial}

Rook ( dalam Fani dan Latifah, 2012 : 25 ) mengatakan bahwa dukungan sosial merupakan salah satu fungsi dari ikatan sosial, dan ikatan - ikatan sosial tersebut menggambarkan tingkat kualitas umum dari hubungan interpersonal.

Menurut Weiss ( Baron dan Kerr, 2003 : 180 ) membagai dukungan sosial ke dalam enam dimensi yaitu :

a. Kelekatan, merasakan dukungan emosional, kedekatan dan menyukai dalam kelompok. Dibina dengan kasih sayang, kepedulian dan perhatian anggota kelompok.

b. Bimbingan, berupa memberikan informasi, nasehat dan umpan balik yang disediakan oleh kelompok.

c. Bantuan Nyata, berupa bantuan material, keuangan atau bnatuan berbentuk pelayanan.

d. Terlibat dalam jaringan sosial, merasa diterima dan merasa bagian dari kelompok membuat individu merasakan identitas. e. Kesempatan untuk mengasuh, bergantung dengan orang lain dan merasakan dibutuhkan orang lain.

f. Pengakuan, Penerimaan, kasih sayang dan menghormati dapat membuat individu merasa memiliki harga diri dan kecukupan diri.

\section{KERANGKA BERPIKIR}

Remaja yang tinggal dilingkungan baru biasanya butuh waktu untuk dapat melakukan penyesuaian diri. Hurlock ( 1994 ) menyatakan bahwa masa remaja dianggap sebagai masa labil yaitu dimana individu berusaha mencari jati dirinya dan mudah sekali menerima informasi dari luar dirinya tanpa ada pemikiran lebih lanjut. Penyesuaian diri menuntut kemampuan remaja untuk hidup dan bergaul secara wajar terhadap lingkungannya.

Selain penyesuaian diri perlu ditinjau pula individu yang memiliki konsep diri yang baik. Chaplin ( dalam Yudit 2008 : 147 ) mengemukakan bahwa konsep diri adalah evaluasi individu mengenai dirinya sendiri, penilaian atau penaksiran mengenai diri sendiri oleh individu yang bersangkutan. Oleh karena itu konsep diri sangat berperan terhadap penyesuaian diri remaja.

Selain konsep diri untuk dapat melakukan penyesuaian diri remaja juga membutuhkan dukungan sosial. Dukungan sosial dari lingkungan dimana remaja itu berada berpengaruh terhadap terbentuknya penyesuaian diri. Menurut House (dalam Fani 2012:29) dukungan sosial merupakan hubungan interpersonal yang didalamnya berisi pemberian bantuan yang melibatkan aspek - aspek yang terdiri dari informasi, perhatian emosional, penghargaan dan bantuan instrumental yang diperoleh individu melalui interaksi dengan lingkungan.

\section{HIPOTESIS}


Ha 1: Adanya hubungan antara konsep diri dengan penyesuaian diri pada remaja di panti sosial bina remaja taruna jaya Tebet Jakarta.

Ha 2 : Adanya hubungan antara dukungan sosial dengan penyesuaian diri pada remaja di panti sosial bina remaja taruna jaya Tebet Jakarta.

Ha3 : Adanya hubungan antarakonsep diri dan dukungan sosial dengan penyesuaian diri pada remaja di panti sosial bina remaja taruna jaya Tebet Jakarta.

\section{METODE PENGUMPULAN DATA}

Jenis skala dalam penelitian ini ialah skala Likert yang terdiri dari skala penyesuaian diri, skala konsep diri, dan skala dukungan sosial. Skala Likert digunakan untuk mengukur sikap, pendapat, dan persepsi seseorang atau sekelompok orang tentang fenomena sosial (Sugiyono, 2010 : 134) yang memiliki lima alternatif jawaban terdiri dari Sangat Sesuai (SS), Sesuai (S), Netral (N), Tidak Sesuai (TS) dan Sangat Tidak Sesuai (STS).

\section{METODE ANALISIS DATA}

Dalam penelitian ini metode yang digunakan dalam menguji hipotesis dan menganalisa data menggunakan metode korelasi bivariate dan korelasi multivariate.

\section{HASIL PENELITIAN}

Dalam penelitian ini, teknik perhitungan korelasi menggunakan rumus bivariate correlation dan multivariate correlation. Pada hipotesis pertama dari hasil analisis data uji koefisien korelasi konsep diri dengan penyesuaian diri diperoleh $\mathrm{r}=$ 0,471 dan $p=0,002, p<0,01$. Hal ini berarti bahwa $\mathrm{Ho}_{1}$ di tolak dan $\mathrm{Ha}_{1}$ yang berbunyi "ada hubungan konsep diri dengan penyesuaian diri pada remaja di panti sosial bina remaja taruna jaya Tebet Jakarta" diterima. Hal ini menunjukkan ada hubungan ke arah positif pada konsep diri dan penyesuaian diri pada remaja di panti sosial bina remaja taruna jaya Tebet Jakarta.

Pada hipotesis kedua juga menggunakan korelasi bivariate dimana hasil analisis data dukungan sosial dengan peneyesuaian diri diperoleh $\mathrm{r}=0,452$ dan $\mathrm{p}$ $=0,003, p<0,01$. Hal ini berarti bahwa $\mathrm{Ho}_{2}$ di tolak dan $\mathrm{Ha}_{2}$ yang berbunyi "ada hubungan dukungan sosial dengan penyesuaian diri pada remaja di panti sosial bina remaja taruna jaya Tebet Jakarta" diterima. Hal ini menunjukkan bahwa ada hubungan ke arah positif dukungan sosial dengan penyesuaian diri pada remaja di panti sosial bina remaja taruna jaya Tebet Jakarta.

Pada hipotesis ketiga menggunakan analisis multivariate correlation dan diperoleh koefisien korelasi (R) antara konsep diri dan dukungan sosial dengan penyesuaian diri sebesar, 0,571 $\mathrm{R}$ Square sebesar 0,326 serta $p=0,000$ dimana $p<$ 0,05 . Hal ini berarti Hal ini berarti bahwa $\mathrm{Ho}_{3}$ di tolak dan $\mathrm{Ha}_{3}$ yang berbunyi "Ada hubungan antara konsep diri dan dukungan sosial dengan penyesuaian diri pada remaja di Panti Sosial Bina Remaja Taruna Jaya Tebet Jakarta" diterima. Hal ini menunjukkan ada hubungan ke arah positif konsep diri dan dukungan sosial dengan penyesuaian diri pada remaja di Panti Sosial Bina Remaja Taruna Jaya Tebet Jakarta.

Dari hasil analisis regresi multivariate kontribusi konsep diri dan dukungan sosial diperoleh $32,6 \%$ dan sisanya dari faktor lainnya.

\section{PEMBAHASAN}

Dari hasil penelitian untuk uji hipotesis secara bivariate antara variabel konsep diri dengan penyesuaian diri diperoleh nilai koefisien korelasi (rxy1) sebesar 0,471 dengan $\mathrm{p}=0,002<0,05$. Maka 
diketahui terdapat hubungan positif antara konsep diri dengan penyesuaian diri. Hal ini menunjukan ada hubungan antara konsep diri dan penyesuaian diri pada remaja di Panti Sosial Bina Remaja Taruna Jaya Tebet Jakarta. Hasil korelasi dengan arah positif menunjukan bahwa semakin tinggi konsep diri, maka semakin tinggi pula tinggi penyesuaian diri. Begitu pula sebaliknya, remaja yang memiliki konsep diri rendah, maka semakin rendah pula tingkat penyesuaian diri.

Hasil penelitian untuk uji hipotesis secara bivariate antara variabel dukungan sosial dengan penyesuaian diri diperoleh nilai koefisien korelasi (rxy2) sebesar 0,452 dengan $\mathrm{p}=0,003<$ 0,05 . Maka diketahui bahwa terdapat hubungan positif antara dukungan sosial dengan penyesuaian diri. Hal ini menunjukan ada hubungan antara dukungan sosial dengan penyesuaian diri pada remaja di Panti Sosial Bina Remaja Taruna Jaya Tebet Jakarta. Hasil korelasi dengan arah positif menunjukan bahwa semakin tinggi dukungan sosial, maka semakin tinggi pula tingkat penyesuaian diri dan sebaliknya semakin rendah dukungan sosial, maka semakin rendah pula tingkat penyesuaian diri.

Hasil penelitian untuk uji hipotesis korelasi multivariate antara variabel konsep diri dan dukungan sosial dengan penyesuaian diri di peroleh nilai $\mathrm{R}$ sebesar 0,571 dengan $p=0,000<0,05$. Maka diketahui bahwa ada hubungan positif antara konsep diri dan dukungan sosial dengan penyesuaian diri pada remaja di Panti Sosial Bina Remaja Taruna Jaya Tebet Jakarta.

\section{KESIMPULAN}

1.Ada hubungan dengan arah positif antara konsep diri dengan penyesuaian diri pada remaja di Panti Sosial Bina Remaja Taruna Jaya Tebet Jakarta
2.Ada hubungan dengan arah positif antara dukungan sosial dengan penyesuaian diri pada remaja di Panti Sosial Bina Remaja Taruna Jaya Tebet Jakarta

3.Ada hubungan positif antara konsep diri dan dukungan sosial dengan penyesuaian pada remaja

di Panti Sosial Bina Remaja Taruna Jaya Tebet Jakarta.

\section{SARAN}

\section{Saran Teoritis}

Bagi peneliti selanjutnya, diharapkan untuk meneliti lebih lanjut mengenai penyesuaian diri dengan mencari faktor lain yang tidak dimasukan dalam penelitian ini, serta dapat menggunakan jumlah populasi yang lebih banyak.

\section{Saran Praktis}

a. Bagi Remaja Panti Sosial Bina Remaja Taruna Jaya JakartaBagi remaja diharapkan dapat mempertahankan penyesuiaan diri dengan cara memahami hidup sesuai realita, dapat melihat kelebihan dan kekurangan diri serta memiliki hubungan interpersonal yang baik. Dan juga dapat meningkatkan konsep diri dengan cara mengenali identitas diri, penerimaan diri, mengenali diri pribadi dan keluarga serta sosial. Dan lebih ditingkatkan untuk dukungan sosialnya dengan cara memiliki kelekatan emosional dengan teman maupun pengurus panti.

b. Bagi Panti Sosial Bina Remaja Taruna Jaya Panti Sosial Bina Remaja Taruna Jaya dapat membantu remaja binaan sosial dalam mempertahankan penyesuaian diri dengan cara menjalin hubungan interpersonal yang lebih erat lagi. Mempertahankan konsep diri dnegan cara membantu remaja panti mengetahui kelebihan dan kekurangan diri. Kemudian membantu 
meningkatkan dukungan sosial dengan cara, lebih memperhatikan remaja panti serta membuat remaja merasa dibutuhkan orang lain.

\section{DAFTAR PUSTAKA}

Ayu Nuzulia Rahma. (2011). Hubungan Efikasi Diri dan Dukungan Sosial dengan Penyesuaian Diri Remaja di Panti Asuhan. Jurnal Psikologi Islam, Vol 8 No. 2.

Desminta. (2009).Psikologi Perkembangan Peserta Didik. PT.Remaja Rosda Karya.

Enung Fatimah M.M. (2006). Psikologi Perkembangan (Perkembangan Peserta Didik). Bandung .CV Pustaka Setia.

Fani Kumalasari \& Latifah Nur Ahyani. (2012). Hubungan Antara Dukungan Sosial dengan Penyesuaian Diri Remaja di Panti Asuhan. Jurnal Psikologi Pitutur, Vol 1 No. 1.

Hendriarti Agustiani.(2009). Psikologi Perkembangan Pendekatan Ekologi Kaitannya dengan Konsep DiriPenyesuaian Diri Pada Remaja.Bandung. PT Refika Aditama

Ida Ayu Ratih Tricahyani \& Putu Nugrahaeni Widiasavitri. (2016). Hubungan Antara Dukungan Sosial dengan Penyesuaian Diri Pasa Remaja Awal di Panti Asuhan Kota Denpasar. Jurnal Psikologi Udayana, Vol 3 No. 3.

Kerlinger, Fred. N. (2004). Asas-asas Penelitian Behavioral Edisi Ketiga. Yogyakarta : Gadjah Mada University Press.

Kuncono Teguh Yunanto. (2005). Aplikasi Komputer Psikologi Edisi II: Diktat Kuliah dan Panduan Praktikum. Jakarta : FPsi UPI YAI.
M.Nur Ghufron \& Rini Risnawita S. (2014). Teori - Teori Psikologi. Jogjakarta. AR- RUZZ MEDIA.

Mutammimah. (2014). Hubungan Konsep Diri dan Kecerdasan Emosi dengan Kemempuan Penyesuaian Diri pada Remaja. Jurnal Psikologi Indonesia, Vol 3 No. 1.

Namora Lumongga Lubis. ( 2009 ). Depresi Tinjauan Psikologis. Jakarta. Kencana Prenada Media Group.

Putri Rosalia Ningrum. ( 2013 ). Perceraian Orang Tua dan Penesuaian Diri Remaja. Ejournal Psikologi Fisip-Unmul, Vol 1 No. 1.

Robert S. Baron \& Norbert L. Kerr. ( 2003 ). Group Process, Group Decision, Group Action. Buckingham Philadlphia.Open Univercity Press.

Saifudin Azwar. (2014). Dasar-dasar Psikometri. Yogyakarta : Pustaka Pelajar.

Sugiyono (2010). Metode Penelitian Pendidikan: Pendekatan Kuantitatif, Kualitatif, dan R\&D. Bandung: Alfabeta.

Sunarto \& B. Agung Hartono. ( 2002 ). Perkembangan Peserta Didik. Jakarta. Rineka Cipta.Y

Yudit Oktaria Kristiani Pardede. ( 2008 ). Konsep Diri Anak Jalanan Usia Remaja. Jurnal Psikologi, Vol 1 No. 2. 
